\title{
Multilocus sequence typing analysis of Candida africana from vulvovaginal candidiasis
}

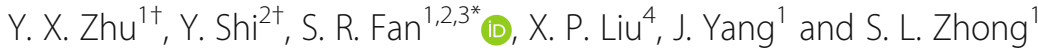

\begin{abstract}
Background: Candida africana is distributed worldwide and colonized in human genitalia and cause mainly vulvovaginal candidiasis (WC). We report the multilocus sequence typing (MLST) analysis of C. africana from WC.

Methods: MLST analysis of 43 strains of $C$. africana, which were isolated from vaginal specimens of patients with WC, was performed. The enzymatic activity of phospholipase, esterase and haemolysis enzyme production was evaluated.The level of virulent genes and resistant genes mRNA expression was determined by using real-time PCR. Antifungal susceptibilities of the isolates were assayed by using the broth microdilution method. The statistical of the results was determined by the $T$ test and Pearson chi-squared test.

Results: The MLST analysis revealed a substantial degree of genetic homogeneity. The DST782 and DST182 were the main MLST genotypes in C. africana. All the patients were symptomatic and with a high mycological cure rate when treated with commonly used antifungal agents.There were statistically significant differences in biofilm formation and phospholipase activity between C. africana and C.albicans. The level of virulent genes and resistant genes mRNA expression was higher in fluconazole-resistant strains. All C. africana isolates were susceptible to fluconazole, itraconazole, voriconazole, caspofungin, and micafungin. These isolates also exhibited low MICs to amphotericin B, flucytosine, and posaconazole.

Conclusions: Candida africana appear to be with a low level of sequence variation in MLST loci. Candida africana, a lower virulence candida, is susceptible to commonly used antifungal agents.

This paper was presented at the conference of 8th Trend in Medical Mycology (6-9 October 2017, Belgrade, Serbia) and was published on conference abstract.
\end{abstract}

Keywords: Vulvovaginal candidiasis, Candida africana, Multilocus sequence typing, Susceptibilities, Biofilm

\section{Background}

Candida africana was isolated, for the first time, in 1995 in Madagascar, Africa and afterwards proposed as new Candida species phylogenetically closely related to $C$. albicans [1]. The isolates assigned to this group were originally proposed as representatives of a new species rather than a biovariant of $C$. albicans. And it shows remarkable differences if compared to C. albicans such as

\footnotetext{
* Correspondence: fanshangrong@163.com

${ }^{\dagger}$ Y. X. Zhu and Y. Shi contributed equally to this work.

'Department of Obstetrics and Gynecology, Peking University Shenzhen Hospital, Shenzhen, China

${ }^{2}$ Clinical College of Peking University Shenzhen Hospital, Anhui Medical

University, Hefei, Anhui, China

Full list of author information is available at the end of the article
}

the taxonomic status. It has been reported that C. africana showed poor adhesion ability to human Hela cells, absence of biofilm formation, a notable low level of filamentation and significantly less pathogenic than C. albicans in the galleria mellonella insect systemic infection model [2-4]. Candida africana represents the phenotypic variation occurring in C. albicans [5]. Candida africana colonized mainly in human genitalia and cause vaginal infections $[6,7]$. Its distribution appears to be worldwide [5-12]. The purpose of this study was to explore multilocus sequence typing (MLST) analysis of $C$. africana from vulvovaginal candidiasis and its relevance to clinical characteristics, virulence, pathogenicity, and antifungal profiles.

(c) The Author(s). 2019 Open Access This article is distributed under the terms of the Creative Commons Attribution 4.0 International License (http://creativecommons.org/licenses/by/4.0/), which permits unrestricted use, distribution, and 
Table 1 Demographic and clinical characteristics of 34 patients with vulvovaginal candidiasis caused by C. africana

\begin{tabular}{ll}
\hline Characteristics & $n(\%)$ \\
\hline Mean age (years old) & $31.15 \pm 7.58$ \\
Duration (months) & $33.97 \pm 127.27$ \\
Antibiotics (in prior 6 weeks, oral or vaginal) & $2(5.9 \%)$ \\
Antifungal on or recent (prior 6 weeks) & $4(11.8)$ \\
Symptoms and signs & \\
Pruritis & $32(94.2)$ \\
Soreness & $13(38.3)$ \\
Discharge & $30(5.9)$ \\
$\quad$ Erythema & $26(76.5)$ \\
Therapy outcome & \\
7-14 days follow up(Negative) & $33(97.1)$ \\
30-35 days fillow up(Negative) & $31(91.2)$ \\
\hline
\end{tabular}

\section{Methods}

\section{Fungal isolates and genotyping}

The isolates were from vaginal specimens of patients with VVC and vaginal samples of pregnant women. Genomic DNA was extracted by using the E.Z.N.A ${ }^{\mathrm{TM}}$ Yeast DNA Kit (OMEGA, USA) according to the manufacturer's instructions HWP1 gene (primers CR-f 5-GCTAC CACTTCAGAATCATCATC-3 and CR-r 5-GCAC CTTC
AGTCGTAGAGACG-3) amplification was performed and the PCR products was electrophoresed in $1.2 \%$ agarose gel in TBE buffer to distinguish C. albicans, C. dubliniensis, and C. africana on the basis of the distinct size of the amplicons as previously described $[9,13]$ (Additional file 6: Figure S1).

The $\mathrm{ABC}$ genotype and mating-type was determined by using previously designed primers and experimental conditions by McCullough et al. [14] and Hull et al. [15]. Multilocus sequence typing for $C$. africana was performed on the basis of a previously published consensus set of seven housekeeping gene loci for $C$. albicans: CaAAT1a, CaACC1, CaADP1, CaMPIb, CaSYA1, CaVPS13 and CaZWF1b [16]. ALL seven loci were sequenced in both the forward and reverse directions and sequence data were assembled using ContigExpress software and checked manually for heterozygous polymorphisms. Allele numbers of each locus was determined by inputting the sequences in the Calbicans MLST database (http://calbicans.mlst.net) and diploid sequence types (DSTs) for each isolate was determined by the composite profile of all seven allele numbers. The MLST results of seven sequenced loci were concatenated into a single sequence to phylogenetic analysis by unweighted-pair group method using average linkages (UPGMA), determined by $P$ distances using MEGA 6 software (http://www.megasoftware.net/).

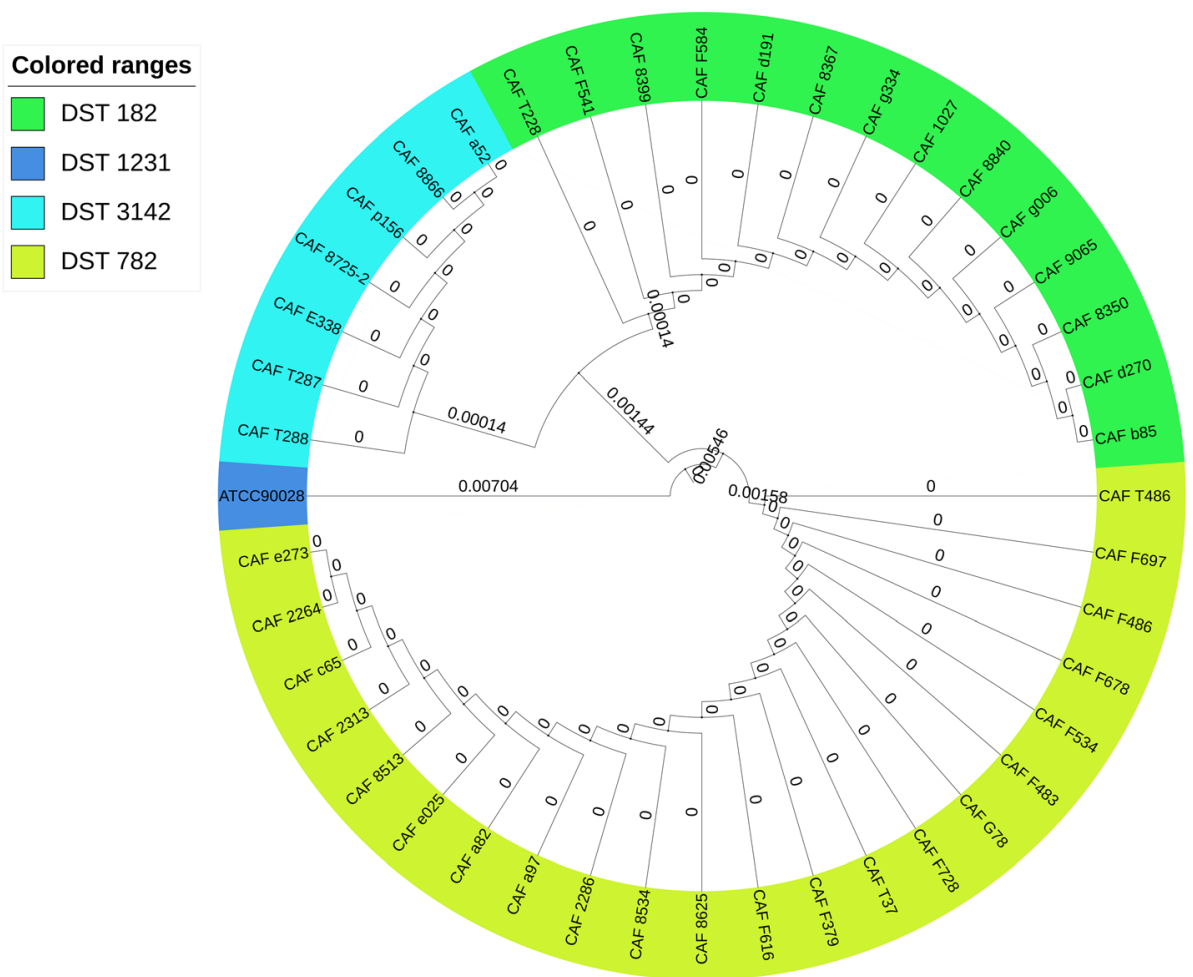

Fig. 1 UPGMA dendrogram of 43 C. africana strains based on the seven loci used in the MLST analysis and DSTs assigned by C. albicans MLST database. 43 C. africana strains were divided into 1 clade in the UPGMA dendrogram. DST782 and DST182 were the main MLST types of C. africana 


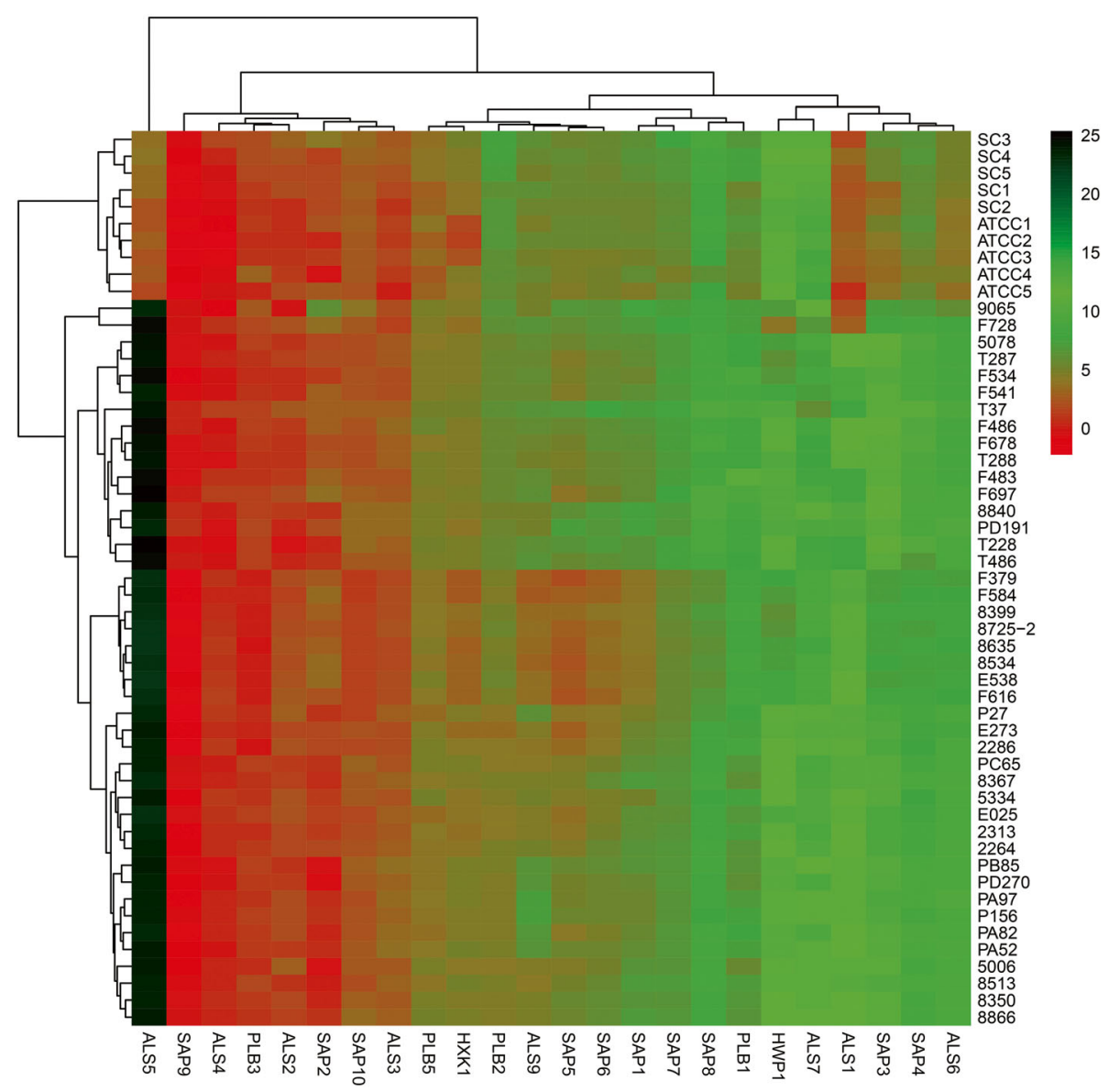

Fig. 2 Expression of the virulence genes in C. africana and C. albicans by quantitative real-time PCR. Compared with the control strains $C$. albicans ATCC90028 and SC5314, the expression of virulent genes ALS1, ALS5, ALS6, SAP3 and SAP4 decreased in C. africana

Candida albicans SC5314 and Candida albicans ATCC90028 were used as reference strains.

\section{Quantitative real-time PCR}

Quantitative real-time PCR analysis of following genes: ALS1-7, ALS9, HWP1, SAP1-SAP10, PLB1-3, PLB5, CDR1, CDR2, MDR1, ERG11 and HXK1 were performed as described by previous publications $[17,18]$. Each experiment was carried out with ACT1 as the housekeeping gene. Data for each target gene were calculated as fold change in comparison with the reference gene ACT1 using the $\Delta \Delta C$ t quantification method. The primers used for quantitative real-time PCR analysis are shown in Additional file 1: Table S1.

\section{Sequencing of the HXK1 gene}

The DNA region of the $H X K 1$ gene carrying the mutation was amplified by or using the primer pair described by Felice et al. [19]. The amplified fragment was sequenced in both directions and sequence data were assembled using ContigExpress and compared with the corresponding wild-type C. albicans and C. africana reference strains respectively.

\section{Extracellular enzymes assays}

The activity of phospholipase, esterase and haemolysis enzyme production was evaluated by or using plate assays methodology described by Pakshir et al. [20] and Sanita et al. [21] with modifications.

\section{Antifungal susceptibility testing}

Susceptibilities of the isolates to antifungal drugs were assayed by the broth microdilution method in 96-well plates according to the proposed Clinical and Laboratory Standards Institute M27-A2 and M27-A3 [22, 23].

\section{Biofilm production assays}

The biofilm production assays was previously published by Pierce al. [24] using a rapid reproducible 96-well microtiter-based method. Each strain was performed in triplicate wells. Quantification of biofilm formation was performed at $8 \mathrm{~h}, 24 \mathrm{~h}, 48 \mathrm{~h}$ and $72 \mathrm{~h}$ respectively after inoculation. 


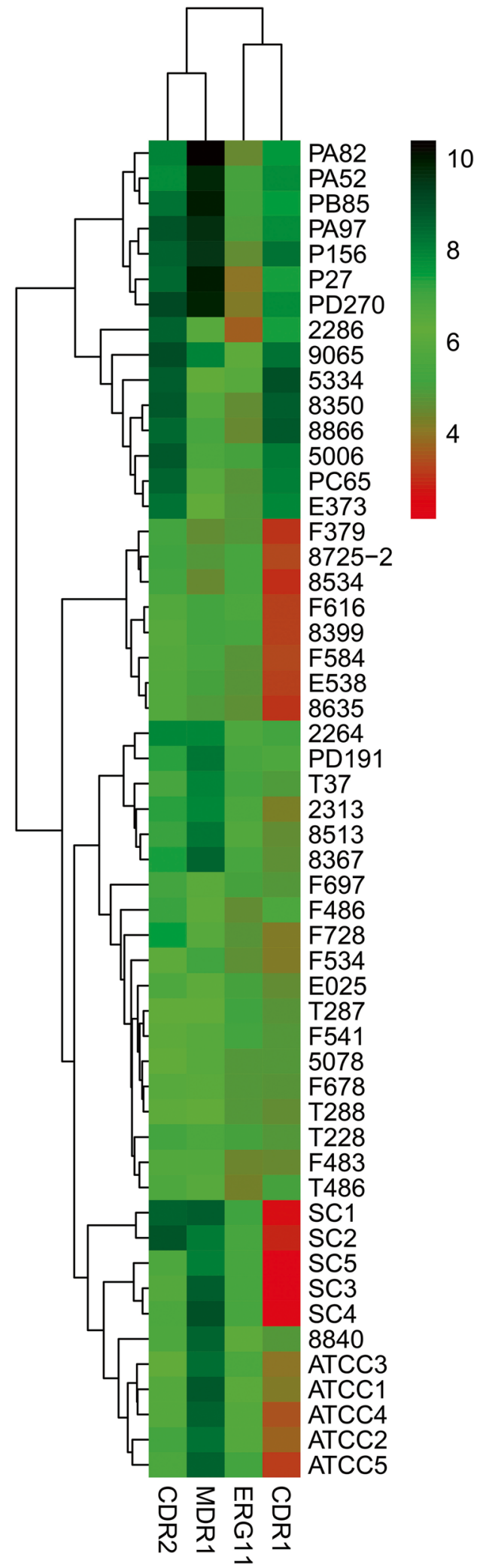

Fig. 3 Expression of the drug resistance genes in C. africana and C. albicans by quantitative real-time PCR. The expression of CDR1, CDR2, and MDR1 varied among C. africana

\section{Statistical analysis}

The statistical significance of the results was determined by the $t$ test and Pearson's chi-squared test, using SPSS version 11.5 (SPSS, Inc., Chicago, IL). The results were considered statistically significant with $P$ values of less than 0.05 .

\section{Results}

The clinical characteristics of VVC caused by C. africana were shown on Table 1 . All the patients were symptomatic. Mycological cure rate of VVC caused by C. africana was $97 \%$ (33/34 cases) and 91\% (31/34 cases) at day 7-14 and day 30-35 follow-up when treated with commonly used antifungal agents (Table 1).

The MLST analysis revealed that the DST782 and DST182 were the main MLST genotypes in C. africana from vaginal specimens of patients with VVC (Fig. 1; Additional file 2: Table S2).

Additional file 8: Figure S3 was electrophoretogram of real time PCR products of virulence genes and drug resistance genes. PCR products of C. africana were electrophoresed in agarose gel in TBE buffer and further verified the correct fragment sizes and specificities of primers used in the study. Compared with C. albicans SC5314 and C. albicans ATCC90028, the expression of virulence genes ALS1, ALS5, ALS6, SAP3 and SAP4 decreased in C. africana strains (Fig. 2; Additional file 4: Table S4).

The expression of drug resistance genes CDR1, CDR2 and MDR1 varied among strains of $C$. africana (Fig. 3; Additional file 3: Table S3). There were statistically significant differences in biofilm formation and phospholipase activity between $C$. africana and C. albicans. Assessment of biofilms at $8 \mathrm{~h}, 24 \mathrm{~h}, 48 \mathrm{~h}$ and $72 \mathrm{~h}$ at OD490 $\mathrm{nm}$ in microtiter plate reader showed biofilm production was significantly lower in C. africana than that in C. albicans (Fig 4).

The sequencing of the partial HXK1-gene of $C$. africana strains showed that the region contained the guanine insertion (Additional file 9: Figure S4). All isolates of C. africana and control C. albicans ATCC 90028 and SC5314 displayed positive phospholipase, hemolytic and esterase activities. However, C. africana showed less active in phospholipase production (Additional file 7: Figure $\mathrm{S2}$ ). All $C$. africana strains examined were unable to produce chlamydospores on cornmeal agar plates supplemented with 1\% Tween 80 (Qingdao Hopebio-Technology, China) and did not grow in tubes containing GlcNAc as the sole carbon source. All C. africana were the genotype A of C. albicans and heterozygous $[\mathrm{a} / \alpha]$ at the mating-type-like locus.

The mycological cure rate of patients infected with $C$. africana was high when treated with commonly used antifungal agents, which was consistent with in vitro antifungal susceptibilities (Table 2). All C. africana isolates 


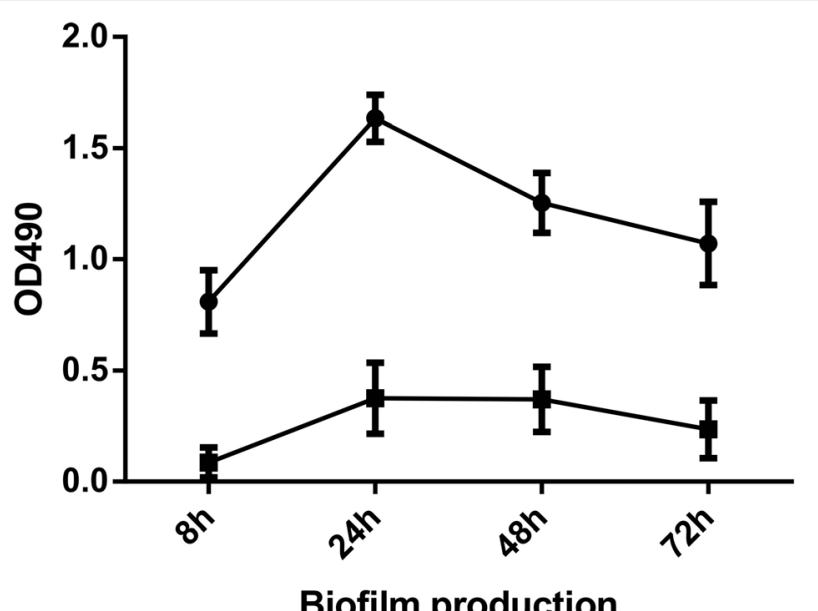

- Candida africana

- Candida albicans

Biofilm production

Fig. 4 Assessment of biofilms at $8 \mathrm{~h}, 24 \mathrm{~h}, 48 \mathrm{~h}$ and $72 \mathrm{~h}$ at OD490 $\mathrm{nm}$ in microtiter plate reader. Biofilm production were significantly lower in C. africana than that in C. albicans

were susceptible to the tested antifungal agents (Tables 3 and 4).

\section{Discussion}

\section{MLST and sequence variability}

Candida africana shows a global distribution and mainly causes genital infections [7]. Review of C. africana in literature has been summarized in Additonal file 5: Table S5 and displayed as a world map in Additonal file 10: Figure S5. By using a single pair of primers derived from HWP1 genes, Romeo and Criseo [13] described an accurate molecular assay for the discrimination among $C$. africana, C. albicans, and C. dubliniensis. DTS182 was the most common and geographically dispersed strain type having been isolated in Europe, South America, Africa and Asia [6-8]. DST782 isolates were the commonest Asian genotype [6, 7]. All these C. africana strains exhibit a phenotypic and genetic homogeneity that is different from their country of origin [7]. In current study, 5 of the 7 MLST loci sequenced showed the same sequences and without single nucleotide polymorphism (SNP) diversity. This suggests a reasonable low level of divergence in the population structure of $C$. africana [7, 10]. The low level of sequence change also suggests that this typing technique may not be ideal for local epidemiological studies $[6,7]$.

Table 2 Therapeutic efficacy in patients with WC caused by candida africana

\begin{tabular}{|c|c|c|c|}
\hline \multirow[t]{2}{*}{ Treatment regimen } & \multirow{2}{*}{$\begin{array}{l}\text { Number } \\
\text { of cases }\end{array}$} & \multicolumn{2}{|c|}{ Cure cases at follow-up (\%) } \\
\hline & & Days $7-14$ & Days $30-35$ \\
\hline Oral fluconazole $150 \mathrm{mg}$ one dose & 2 & 2 & 2 \\
\hline Oral fluconazole $150 \mathrm{mg}$ two doses & 7 & 6 & 6 \\
\hline Oral fluconazole $150 \mathrm{mg}$ three doses & 2 & 2 & 2 \\
\hline Oral itraconazole 200 mg twice daily for one day & 2 & 2 & 2 \\
\hline Oral itraconazole 200 mg twice daily for two days & 4 & 4 & 2 \\
\hline Oral itraconazole $200 \mathrm{mg}$ twice daily for five days & 1 & 1 & 1 \\
\hline Mmiconazole nitrate vaginal suppository $1200 \mathrm{mg}$ one dose & 1 & 1 & 1 \\
\hline Miconazole nitrate vaginal suppository 1200 mg two doses & 4 & 4 & 4 \\
\hline Clotrimazole vaginal tablets $500 \mathrm{mg}$ for 1 day & 2 & 2 & 2 \\
\hline Clotrimazole vaginal tablets $500 \mathrm{mg}$ for 2 days & 5 & 5 & 5 \\
\hline Terconazole vaginal suppository $80 \mathrm{mg}$ for 6 days & 2 & 2 & 2 \\
\hline Nystatin vaginal suppository 200,000 IU daily for 7 days & 1 & 1 & 1 \\
\hline Fluconazole 150 mg two doses together with nystatin vaginal suppository 200,000 IU Daily for 14 days & 1 & 1 & 1 \\
\hline Total & 34 & 33(97.1) & $31(91.2)$ \\
\hline
\end{tabular}


Table 3 In vitro antifungal susceptibilities of 43 clinical C. africana isolates as determined by the Clinical and Laboratory Standards Institute (CLSI) method

\begin{tabular}{|c|c|c|c|c|c|c|c|c|}
\hline Candida species & & BUC & CLO & $\mathrm{FLC}$ & ITC & MIC & TEC & VRC \\
\hline $\begin{array}{l}\text { C. africana } \\
\text { DST } 182 \\
\text { (14) }\end{array}$ & $\begin{array}{l}\text { Range } \\
\text { GM } \\
\text { MIC90 }\end{array}$ & $\begin{array}{l}0.030-1.00 \\
0.096 \\
0.500\end{array}$ & $\begin{array}{l}0.030-1.00 \\
0.044 \\
0.030\end{array}$ & $\begin{array}{l}0.125-2.00 \\
0.540 \\
2.000\end{array}$ & $\begin{array}{l}0.030-0.03 \\
0.030 \\
0.030\end{array}$ & $\begin{array}{l}0.015-0.50 \\
0.083 \\
0.500\end{array}$ & $\begin{array}{l}0.030-0.50 \\
0.047 \\
0.060\end{array}$ & $\begin{array}{l}0.030-0.25 \\
0.037 \\
0.030\end{array}$ \\
\hline $\begin{array}{l}\text { C. africana } \\
\text { DST } 782 \\
(22)\end{array}$ & $\begin{array}{l}\text { Range } \\
\text { GM } \\
\text { MIC90 }\end{array}$ & $\begin{array}{l}0.015-0.25 \\
0.037 \\
0.125\end{array}$ & $\begin{array}{l}0.03-0.125 \\
0.032 \\
0.030\end{array}$ & $\begin{array}{l}0.250-2.00 \\
0.484 \\
1.000\end{array}$ & $\begin{array}{l}0.015-0.03 \\
0.027 \\
0.030\end{array}$ & $\begin{array}{l}0.015-0.25 \\
0.024 \\
0.030\end{array}$ & $\begin{array}{l}0.03-0.125 \\
0.051 \\
0.125\end{array}$ & $\begin{array}{l}0.030-0.06 \\
0.030 \\
0.030\end{array}$ \\
\hline $\begin{array}{l}\text { C. africana } \\
\text { DST } 3142 \\
\text { (7) }\end{array}$ & $\begin{array}{l}\text { Range } \\
\text { GM } \\
\text { MIC90 }\end{array}$ & $\begin{array}{l}0.030-0.50 \\
0.060 \\
0.250\end{array}$ & $\begin{array}{l}0.030-0.03 \\
0.030 \\
0.030\end{array}$ & $\begin{array}{l}0.250-0.50 \\
0.410 \\
0.500\end{array}$ & $\begin{array}{l}0.030-0.03 \\
0.030 \\
0.030\end{array}$ & $\begin{array}{l}0.015-0.50 \\
0.045 \\
0.500\end{array}$ & $\begin{array}{l}0.03-0.125 \\
0.044 \\
0.060\end{array}$ & $\begin{array}{l}0.03-0.125 \\
0.036 \\
0.030\end{array}$ \\
\hline $\begin{array}{l}\text { Sub-total } \\
(43)\end{array}$ & $\begin{array}{l}\text { Range } \\
\text { GM } \\
\text { MIC90 }\end{array}$ & $\begin{array}{l}0.015-1.00 \\
0.051 \\
0.250\end{array}$ & $\begin{array}{l}0.030-1.00 \\
0.034 \\
0.030\end{array}$ & $\begin{array}{l}0.125-2.00 \\
0.482 \\
1.000\end{array}$ & $\begin{array}{l}0.015-0.03 \\
0.028 \\
0.030\end{array}$ & $\begin{array}{l}0.015-0.50 \\
0.036 \\
0.500\end{array}$ & $\begin{array}{l}0.030-0.50 \\
0.049 \\
0.125\end{array}$ & $\begin{array}{l}0.030-0.25 \\
0.033 \\
0.030\end{array}$ \\
\hline $\begin{array}{l}\text { C. albicans ATCC } 90028 \\
\text { (5) }\end{array}$ & $\begin{array}{l}\text { Range } \\
\text { GM } \\
\text { MIC90 }\end{array}$ & $\begin{array}{l}0.03-0.125 \\
0.039 \\
0.125\end{array}$ & $\begin{array}{l}0.030-0.06 \\
0.034 \\
0.060\end{array}$ & $\begin{array}{l}0.500-1.00 \\
0.757 \\
1.000\end{array}$ & $\begin{array}{l}0.030-0.06 \\
0.052 \\
0.060\end{array}$ & $\begin{array}{l}0.030-0.50 \\
0.060 \\
0.500\end{array}$ & $\begin{array}{l}0.030 \\
0.030 \\
0.030\end{array}$ & $\begin{array}{l}0.030 \\
0.030 \\
0.030\end{array}$ \\
\hline
\end{tabular}

BUC butoconazole, CLO Clotrimazole, FLC Fluconazole, ITC Itraconazole, VRC Voriconazole, MIC Miconazole, TEC Terconazole

Phenotypic characterizations, virulence and pathogenicity Compared to C. albicans, C. africana shows remarkable phenotypically differences such as the inability to produce characteristic chlamydospores and the incapacity to assimilate many carbon sources especially $\mathrm{N}$-acetylglucosamine(GlcNAc), which plays an important role in cell signaling $[1,5,25]$. DNA sequence analysis of the HXK1 gene, encoding the enzyme GlcNAc-kinase, demonstrated the existence of a specific mutation [guanine insertion] that impairs GlcNAc assimilation in C. africana [19]. All of our C. africana carried a specific $H X K 1$ gene mutation and were mating-type $\mathrm{a} / \alpha$ and genotype A of $C$. albicans isolates.

Candida africana shows a poor adhesion to human epithelial cells as demonstrated by using both mammalian and insect infection models [2]. In our current study, there were statistically significant differences in biofilm formation, phospholipase activity between $C$. africana and C. albicans. All of our patients were symptomatic, which were consistent within vitro extracellular enzymes assays and the expression of virulence genes.

The clinical signs in the patients infected with C. africana were almost identical with those with C. albicans [9].

\section{Antifungal susceptibilities and therapy outcome}

Candida africana exhibits susceptibility patterns of commonly used antifungal agents similar to those of $C$. albicans [8, 9]. However, Al-Hedaithy and Fotedar [26] reported that chlamydospore-negative combined with germ tube negative isolates were resistant to fluconazole and itraconazole. In agreement with previous reports [6, 8 ,27], our C. africana isolates tested were found to be susceptible to all antifungal agents. Mendling et al. [28] reported that $C$. africana could be eradicated by a single dose vaginal tablet containing $500 \mathrm{mg}$ clotrimazole.

Table 4 In vitro antifungal susceptibilities of 43 clinical C. africana isolates as determined by the Clinical and Laboratory Standards Institute (CLSI) method

\begin{tabular}{|c|c|c|c|c|c|c|c|c|}
\hline Candida species & & AmB & FLU & NYS & TEB & AFG & CFG & MFG \\
\hline $\begin{array}{l}\text { C. africana } \\
\text { DST } 182(14)\end{array}$ & $\begin{array}{l}\text { Range } \\
\text { GM } \\
\text { MIC90 }\end{array}$ & $\begin{array}{l}0.030-0.250 \\
0.052 \\
0.125\end{array}$ & $\begin{array}{l}0.250-8.000 \\
1.166 \\
4.000\end{array}$ & $\begin{array}{l}0.125-4.000 \\
0.734 \\
4.000\end{array}$ & $\begin{array}{l}8.000-256.000 \\
47.031 \\
128.000\end{array}$ & $\begin{array}{l}0.008-0.030 \\
0.015 \\
0.015\end{array}$ & $\begin{array}{l}0.125-0.500 \\
0.396 \\
0.500\end{array}$ & $\begin{array}{l}0.015-0.500 \\
0.056 \\
0.125\end{array}$ \\
\hline $\begin{array}{l}\text { C. africana } \\
\text { DST } 782 \\
(22)\end{array}$ & $\begin{array}{l}\text { Range } \\
\text { GM } \\
\text { MIC90 }\end{array}$ & $\begin{array}{l}0.030-1.000 \\
0.064 \\
0.250\end{array}$ & $\begin{array}{l}0.125-2.000 \\
0.567 \\
2.000\end{array}$ & $\begin{array}{l}0.125-8.000 \\
0.707 \\
4.000\end{array}$ & $\begin{array}{l}4.000-256.000 \\
21.008 \\
128.000\end{array}$ & $\begin{array}{l}0.008-2.000 \\
0.013 \\
0.015\end{array}$ & $\begin{array}{l}0.005-0.500 \\
0.208 \\
0.500\end{array}$ & $\begin{array}{l}0.015-0.125 \\
0.026 \\
0.125\end{array}$ \\
\hline $\begin{array}{l}\text { C. africana } \\
\text { DST } 3142 \\
\text { (7) }\end{array}$ & $\begin{array}{l}\text { Range } \\
\text { GM } \\
\text { MIC90 }\end{array}$ & $\begin{array}{l}0.030-0.125 \\
0.061 \\
0.125\end{array}$ & $\begin{array}{l}0.125-2.000 \\
0.410 \\
1.000\end{array}$ & $\begin{array}{l}0.250-4.000 \\
0.371 \\
0.250\end{array}$ & $\begin{array}{l}4.000-128.000 \\
28.983 \\
64.000\end{array}$ & $\begin{array}{l}0.008-0.015 \\
0.010 \\
0.015\end{array}$ & $\begin{array}{l}0.005-0.500 \\
0.192 \\
0.500\end{array}$ & $\begin{array}{l}0.015-0.125 \\
0.030 \\
0.125\end{array}$ \\
\hline $\begin{array}{l}\text { Sub-total } \\
\text { (43) }\end{array}$ & $\begin{array}{l}\text { Range } \\
\text { GM } \\
\text { MIC90 }\end{array}$ & $\begin{array}{l}0.030-1.000 \\
0.060 \\
0.125\end{array}$ & $\begin{array}{l}0.125-8.000 \\
0.633 \\
2.000\end{array}$ & $\begin{array}{l}0.125-8.000 \\
0.633 \\
4.000\end{array}$ & $\begin{array}{l}4.000-256.000 \\
26.979 \\
128.000\end{array}$ & $\begin{array}{l}0.008-2.000 \\
0.013 \\
0.015\end{array}$ & $\begin{array}{l}0.005-0.500 \\
0.239 \\
0.500\end{array}$ & $\begin{array}{l}0.015-0.500 \\
0.032 \\
0.125\end{array}$ \\
\hline C. albicans ATCC90028 (5) & $\begin{array}{l}\text { Range } \\
\text { GM } \\
\text { MIC90 }\end{array}$ & $\begin{array}{l}1.000 \\
0.375 \\
1.000\end{array}$ & $\begin{array}{l}0.500-1.000 \\
0.250 \\
1.000\end{array}$ & $\begin{array}{l}0.250-0.500 \\
0.435 \\
0.500\end{array}$ & $\begin{array}{l}64.000-256.000 \\
190.74 \\
256.00\end{array}$ & $\begin{array}{l}0.008-0.015 \\
0.009 \\
0.015\end{array}$ & $\begin{array}{l}0.250 \\
0.250 \\
0.250\end{array}$ & $\begin{array}{l}0.008-0.015 \\
0.009 \\
0.015\end{array}$ \\
\hline
\end{tabular}


The mycological cure rate of patients infected with $C$. africana was high when treated with commonly used antifungal agents, which was consistent with in vitro antifungal susceptibilities.

\section{Conclusions}

Candida africana, a worldwide distribution candida, mainly cause vaginal infections and appears to be with a low level of sequence variation in MLST loci. Candida africana, a lower virulence and pathogenicity Candida, is susceptible to commonly used antifungal agents and have a high mycological cure rate.

\section{Additional files}

Additional file 1: Table S1. Primers used for amplification, sequencing and expression analysis in this study. (DOC $55 \mathrm{~kb}$ )

Additional file 2: Table S2. Details of MLST diploid sequence types for 43 C. africana strains. (XLSX $14 \mathrm{~kb}$ )

Additional file 3: Table S3. Expression of the drug resistance genes in C. africana and C. albicans SC5314 and ATCC90028. (XLSX $12 \mathrm{~kb}$ )

Additional file 4: Table S4. Expression of the virulence genes in $C$. africana and C. albicans SC5314 and ATCC90028. (XLSX $21 \mathrm{~kb})$

Additional file 5: Table S5. Review of C. africana in literature. (XLSX 12 $\mathrm{kb})$

Additional file 6: Figure S1. Molecular discrimination of $C$. albicans, $C$. africana, and C. dubliniensis using HWP1 gene. Lanes 1, 4, 5, 6, 8, and 9 are C. albicans; Lanes 7 is C. africana. Lanes 10 is C. dubliniensis CBS 7988. Lane 2 contains molecular size markers. (JPG $351 \mathrm{~kb}$ )

Additional file 7: Figure S2. Extracellular enzymatic activity of $C$. africana isolates. All isolates of $C$. africana and control C. albicans ATCC90028 and SC5314 display positive phospholipase (a, b), hemolytic $(c, d)$ and esterase activities (e, f). C. africana shows less active in phospholipase production (a). (JPG $1751 \mathrm{~kb}$ )

Additional file 8: Figure S3. Real time PCR products of virulence genes and drug resistance genes of C. africana. Upper lane 1 to 16 are PCR products of gene ACT, SAP1, SAP2, SAP3, SAP4, SAP5, SAP6, SAP7, SAP8, SAP9, SAP10, HWP1, PLB1, PLB2, PLB3 and PLB5. Lower lane 1 to 13 are PCR products of gene ACT, ALS1, ALS2, ALS3, ALS4, ALS5, ALS6, ALS7, ALS9, CDR1, CDR2, MDR1 and ERG11. Lane M is molecular size marker. (JPG 1187 $\mathrm{kb})$

Additional file 9: Figure S4. Amplification and sequencing of the partial HXK1-gene sequencing of C. africana and C. albicans ATCC90028. C. africana strain is showing the region containing the guanine insertion. (JPG $595 \mathrm{~kb}$ )

Additional file 10: Figure S5. The world distribution of reported $C$. africana in literature The map was developed by using Adobe Photoshop CS6 (v13.0.1.1, Adobe Systems, San Jose, CA, USA). The copyright holder grants anyone the right to use this work for any purpose, without any conditions, unless such conditions are required by law. https://upload. wikimedia.org/wikipedia/commons/a/a2/2009_Special_301_Report_ \%28World_Map\%29.png. (JPG 3368 kb)

\section{Abbreviations}

ABC: ATP-binding cassette; ALS: Agglutinin-like sequence; CDR: Candida drug resistance; DST: Diploid sequence typing; ERG: Ergosterol; GlcNAc: Nacetylglucosamine; HWP1: Hyphal wall protein 1; HXK1: Hexokinase 1; MDR: Multidrug resistant; MIC: Minimal inhibitory concentration; MLST: Multilocus sequence typing; PCR: Polymerase chain reaction; PLB: Phospholipase B; SAP: Secretory aspartyl proteinase; WC: Vulvovaginal candidiasis

\section{Acknowledgements}

"The Abstract of this study was previously presented at 8th Congress on Trends in Medical Mycology in Belgrade, Serbia".

\section{Funding}

This research was supported by Shenzhen Science and Technology Grant JCYJ JCYJ20160428175005906; SZXJ2017008; Guangdong Science and Technology Grant 2014A020212037.

Availability of data and materials

The datasets used during the current study are available from the corresponding author on reasonable request.

\section{Authors' contributions}

YXZ and YS carried out the molecular genetic studies, participated in the sequence alignment and drafted the manuscript. JY participated in the sequence alignment. XPL participated in the design of the study and performed the statistical analysis. SRF and SLZ conceived of the study, and participated in its design and coordination and helped to draft the manuscript. All authors read and approved the final manuscript.

\section{Ethics approval and consent to participate}

The verbal informed consents were obtained from all individual participants included in the study. The study and the informed consents procedure were approved by Peking University Shenzhen Hospital Medical Ethics Committee (2017[024]).

\section{Consent for publication}

Not applicable.

\section{Competing interests}

The authors declare that they have no competing interests.

\section{Publisher's Note}

Springer Nature remains neutral with regard to jurisdictional claims in published maps and institutional affiliations.

\section{Author details}

'Department of Obstetrics and Gynecology, Peking University Shenzhen Hospital, Shenzhen, China. ${ }^{2}$ Clinical College of Peking University Shenzhen Hospital, Anhui Medical University, Hefei, Anhui, China. ${ }^{3}$ Shenzhen Key Laboratory on Technology for Early Diagnosis of Major Gynecological Diseases, Shenzhen, China. ${ }^{4}$ Department of Laboratory Science, Peking University Shenzhen Hospital, Shenzhen, China.

Received: 1 May 2018 Accepted: 7 May 2019

Published online: 22 May 2019

\section{References}

1. Tietz HJ, Küssner A, Thanos M, de Andrade MP, Presber W, Schönian G. Phenotypic and genotypic characterization of unusual vaginal isolates of Candida albicans from Africa. J Clin Microbiol. 1995;33:2462-5.

2. Romeo O, De Leo F, Criseo G. Adherence ability of Candida africana: a comparative study with Candida albicans and Candida dubliniensis. Mycoses. 2011;54:57-61.

3. Borman AM, Szekely A, Linton CJ, Palmer MD, Brown P, Johnson EM. Epidemiology, antifungal susceptibility, and pathogenicity of Candida africana isolates from the United Kingdom. J Clin Microbiol. 2013;51:967-72.

4. Pagniez F, Jimenez-Gil P, Mancia A, Le Pape P. Étude comparative in vivo de la virulence de Candida africana et de C. albicans stricto sensu. J Mycol Med. 2015;25:107.

5. Tietz HJ, Hopp M, Schmalreck A, Sterry W, Czaika V. Candida africana sp. nov., a new human pathogen or a variant of Candida albicans? Mycoses. 2001:44:437-45.

6. Hu Y, Yu A, Chen X, Wang G, Feng X. Molecular characterization of Candida africana in genital specimens in Shanghai, China. Biomed Res Int. 2015;2015: 185387

7. Chowdhary A, Hagen F, Sharma C, Al-Hatmi AM, Giuffrè L, Giosa D, et al. Whole genome-based amplified fragment length polymorphism analysis reveals genetic diversity in Candida africana. Front Microbiol. 2017;8:556. 
8. Odds FC, Bougnoux ME, Shaw DJ, Bain JM, Davidson AD, Diogo D, et al. Molecular phylogenetics of Candida albicans. Eukaryot Cell. 2007;6:1041-52.

9. Shan Y, Fan S, Liu X, Li J. Prevalence of Candida albicans-closely related yeasts, Candida africana and Candida dubliniensis, in vulvovaginal candidiasis. Med Mycol. 2014;52:636-40.

10. Sharma C, Muralidhar S, Xu J, Meis JF, Chowdhary A. Multilocus sequence typing of Candida africana from patients with vulvovaginal candidiasis in New Delhi, India. Mycoses. 2014;57:544-52.

11. Yazdanparast SA, Khodavaisy S, Fakhim H, Shokohi T, Haghani I, Nabili M, et al. Molecular characterization of highly susceptible Candida africana from vulvovaginal candidiasis. Mycopathologia. 2015;180:317-23.

12. Theill L, Dudiuk C, Morano S, Gamarra S, Nardin ME, Mendez E, et al. Prevalence and antifungal susceptibility of Candida albicans and its related species Candida dubliniensis and Candida africana isolated from vulvovaginal samples in a hospital of Argentina. Rev Argent Microbiol. 2016; 48:43-9.

13. Romeo O, Criseo G. First molecular method for discriminating between Candida africana, Candida albicans, and Candida dubliniensis by using hwp1 gene. Diagn Microbiol Infect Dis. 2008;62:230-3.

14. McCullough MJ, Clemons KV, Stevens DA. Molecular and phenotypic characterization of genotypic Candida albicans subgroups and comparison with Candida dubliniensis and Candida stellatoidea. J Clin Microbiol. 1999:37:417-21.

15. Hull CM, Johnson AD. Identification of a mating type-like locus in the asexual pathogenic yeast Candida albicans. Science. 1999;285:1271-5.

16. Bougnoux ME, Tavanti A, Bouchier C, Gow NA, Magnier A, Davidson AD, et al. Collaborative consensus for optimized multilocus sequence typing of Candida albicans. I Clin Microbiol. 2003;41:5265-6.

17. Chau AS, Mendrick CA, Sabatelli FJ, Loebenberg D, McNicholas PM. Application of real-time quantitative PCR to molecular analysis of Candida albicans strains exhibiting reduced susceptibility to azoles. Antimicrob Agents Chemother. 2004;48:2124-31.

18. Correia A, Lermann U, Teixeira L, Cerca F, Botelho S, Gil da Costa RM, et al. Limited role of secreted aspartyl proteinases Sap1 to Sap6 in Candida albicans virulence and host immune response in murine hematogenously disseminated candidiasis. Infect Immun. 2010;78:4839-49.

19. Felice MR, Gulati M, Giuffre L, Giosa D, Di Bella LM, Criseo G, et al. Molecular characterization of the $\mathrm{N}$-acetylglucosamine catabolic genes in Candida africana, a natural $\mathrm{N}$-acetylglucosamine kinase (HXK1) mutant. PLoS One. 2016;11:e0147902.

20. Pakshir K, Zomorodian K, Karamitalab M, Jafari M, Taraz H, Ebrahimi H. Phospholipase, esterase and hemolytic activities of Candida spp. isolated from onychomycosis and oral lichen planus lesions. J Mycol Med. 2013;23:113-8.

21. Sanita PV, Zago CE, Mima EG, Pavarina AC, Jorge JH, Machado AL, et al. In vitro evaluation of the enzymatic activity profile of non-albicans Candida species isolated from patients with oral candidiasis with or without diabetes. Oral Surg Oral Med Oral Pathol Oral Radiol. 2014;118:84-91.

22. National Committee for Clinical Laboratory Standards [CLSI]. Reference method for broth dilution antifungal susceptibility testing for yeasts. Approved standard M27-A2. 2nd ed. Wayne: National Committee for Clinical Laboratory Standards; 2008.

23. National Committee for Clinical Laboratory Standards [CLSI]. Reference method for broth dilution antifungal susceptibility testing for yeasts. Approved standard M27-A3. 2nd ed. Wayne: National Committee for Clinical Laboratory Standards; 2012.

24. Pierce CG, Uppuluri P, Tummala S, Lopez-Ribot JL. A 96 well microtiter plate-based method for monitoring formation and antifungal susceptibility testing of Candida albicans biofilms. J Vis Exp. 2010;(44):e2287.

25. Rao KH, Ghosh S, Natarajan K, Datta A. N-acetylglucosamine kinase, HXK1 is involved in morphogenetic transition and metabolic gene expression in Candida albicans. PLoS One. 2013;8:e53638.

26. Al-Hedaithy S, Fotedar R. Recovery and studies on chlamydospore-negative Candida albicans isolated from clinical specimens. Med Mycol. 2002;40:301-6.

27. Hasanvand S, Azadegan Qomi H, Kord M, Didehdar M. Molecular epidemiology and in vitro antifungal susceptibility of Candida isolates from women with vulvovaginal candidiasis in northern cities of Khuzestan Province. Iran Jundishapur J Microbiol. 2017;10(8):e12804.

28. Mendling W, Krauss C, Fladung B. A clinical multicenter study comparing efficacy and tolerability of topical combination therapy with clotrimazole (Canesten ${ }^{\oplus}$, two formats) with oral single dose fluconazole (Diflucan ${ }^{\oplus}$ ) in vulvovaginal mycoses. Mycoses. 2004;47:136-42.

Ready to submit your research? Choose BMC and benefit from:

- fast, convenient online submission

- thorough peer review by experienced researchers in your field

- rapid publication on acceptance

- support for research data, including large and complex data types

- gold Open Access which fosters wider collaboration and increased citations

- maximum visibility for your research: over $100 \mathrm{M}$ website views per year

At $\mathrm{BMC}$, research is always in progress.

Learn more biomedcentral.com/submissions 